\title{
Supporting sustainable groundwater management
}

by Faith Kearns and Doug Parker

Flooding an alfalfa field for a groundwater recharge research project. mplementation of the 2014 Sustainable Groundwater Management Act is on schedule. The first phase, completed in 2017, created a new layer of local government - groundwater sustainability agencies (see Conrad et al. research article, page 44).

Now, these new agencies must prepare groundwater sustainability plans (see Mehta et al. research article, page 54). These plans will lay out a basic reckoning for every overdrafted basin: without additional water to replace groundwater pumping or to recharge aquifers, there will be less available to produce food, supply homes and businesses, and ensure there is enough water for the environment.

UC Agriculture and Natural Resources (UC ANR) is working to develop one of the most promising groundwater recharge approaches - replenishing aquifers by spreading wintertime river flood flows onto farm lands and other open spaces. It's an effort that illustrates the core strengths of UC ANR and UC Cooperative Extension - research and partnerships.

UC ANR researchers have mapped recharge-relevant soil conditions across the state to identify the most promising sites for deliberate recharge (O'Geen et al. 2015). Demonstration projects with private-sector partners (Bachand 2016) have begun to illuminate the costs and operational considerations for farm-based recharge projects. And in this issue of California Agriculture, Dahlke et al. (page 65) report the results of field trials suggesting that alfalfa - already one of the most promising crop candidates for farm-field recharge - tolerates cool-season flooding well.

On-farm groundwater recharge takes advantage of the water capture, filtration and storage services provided by natural and working landscapes - water is held by plants and absorbed by the soil (rather than running off), cleaned as it percolates through the soil profile, and stored underground. Wintertime flood flows are being targeted because they may provide water that is essentially "surplus" - not claimed by another user, not needed to maintain the health of downstream ecosystems, and beyond what can be stored in the state's surface water reservoirs.

The potential of this type of recharge is vast. Available aquifer storage capacity far exceeds the total capacity of all the state's surface-water reservoirs, and studies suggest that new groundwater storage can be developed at about one-sixth the cost of new surface water storage (Perrone and Rohde 2014).

Realizing that potential is another matter. One major obstacle is that implementing such projects requires a great deal of coopera-

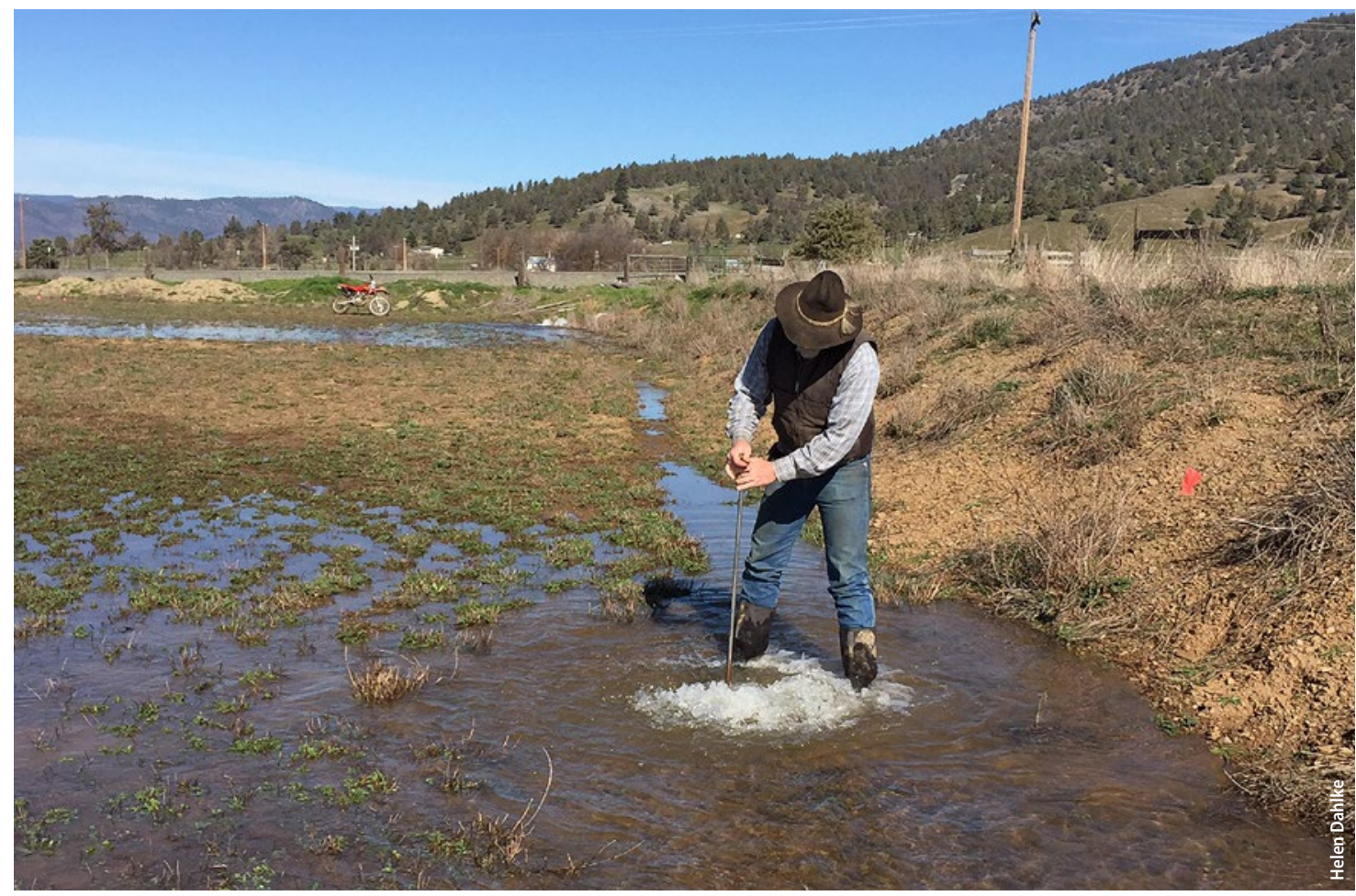
tion and coordination. Farms and groundwater sustainability agencies can't fully implement recharge projects on their own. They will need to work in partnership with surface water suppliers, flood control agencies, water regulators, wildlife conservation agencies and organizations, local land use planners, water rights attorneys and many others.

To address the collaborative aspect of this challenge, UC ANR Vice President Glenda Humiston, in partnership with the California Economic Summit, has brought together experts and decision-makers 
from around the state - hydrologists, land-use planners, engineers, agency leaders, attorneys, local officials, and more - to build a strategy. At a meeting in Davis hosted by UC ANR, the group developed a series of actions, policies and funding mechanisms (see box) to promote the development of groundwater recharge projects, ideas that were then presented at the California Economic Summit in San Diego in November. The group's work is continuing in 2018.

There are reasons for optimism. In Fresno, for instance, city officials have partnered with the local flood control district to use flood control basins for recharge, sending 50,000 acre-feet of water into underground storage annually. The city has also adopted plans to preserve open space suitable for recharge, and to lease or purchase vacant parcels for use as recharge basins. The adoption of similar actions and policies in other cities around the state, especially in agricultural regions, could substantially increase annual recharge.

The need to increase recharge, of course, is just one piece of California's groundwater puzzle.

As this special issue illustrates, UC ANR and its partners are working in a variety of other ways to support sustainable groundwater management. In San Luis Obispo County, UCCE Farm Advisor Mark Battany's work (page 76) has helped to efficiently estimate recent rates of groundwater pumping for vineyards, generating data now being used in the development of the region's groundwater sustainability plans. In the Scott Valley in Siskiyou County, the work of Laura Foglia and Thomas Harter of UC Davis, the late UCCE Farm Advisor Steve Orloff, and their collaborators (page 84) illuminates interactions between surface water and groundwater. UC Davis Ph.D. Meredith Niles (now a professor at the University of Vermont) and her collaborators are working to improve our understanding of farmers' perspectives on SGMA and its implementation (page 38). The review paper by UC Davis Agricultural and Resource Economics Professor Emeritus Richard Howitt and his collaborators (page 28) provides lessons from the experiences of 18 adjudicated or otherwise regulated groundwater basins across the western states. And the research news section of this issue provides a roundup of many more projects under way across the UC system.

\section{References}

Bachand P, Roy S, Stern N, et al. 2016. On-farm flood capture could reduce groundwater overdraft in Kings River Basin. Calif Agr 70:200-7. https://doi.org/10.3733/ca.2016a0018

O'Geen AT, Saal M, Dahlke H, et al. 2015. Soil suitability index identifies potential areas for groundwater banking on agricultural lands. Calif Agr 69:75-84. https://doi.org/10.3733/ ca.v069n02p75

Perrone D, Rohde M. 2014. Storing water in California: What can $\$ 2.7$ billion buy us? Research Brief. Water in the West program, Stanford University. http://waterinthewest.stanford.edu/sites/ default/files/Storing_Water_in_CA.pdf
All of these perspectives will be important as California moves toward sustainable management of its groundwater resources while also seeking to maintain the health of its rural communities and agricultural economy. CA

Faith Kearns is Academic Coordinator, California Institute for Water Resources, UC Agriculture and Natural Resources. Doug Parker is Director, California Institute for Water Resources and Iniative Leader, UC Agriculture and Natural Resources Water Quality, Quantity and Security Strategic Initiative.

\section{Promoting groundwater recharge on working lands and open space}

\section{Recommendations from a multidisciplinary group of experts convened by UC ANR and the California Economic Summit. More at: https://goo.gl/ onAE1T}

- Prioritize multi-agency partnerships through decisions on state funding of groundwater recharge projects.

- Establish a state task force to identify barriers to new groundwater recharge projects.

- Require the consideration of groundwater recharge sites in General Plan updates (the primary planning documents produced by local governments).

- Support continuous improvement in publicly available spatial data on suitable groundwater recharge locations.

- Make groundwater recharge a standard part of local land use planning and local and regional water planning.

- Align policies to support groundwater recharge on agricultural lands, including those governing water rights, water quality standards, permitting, habitat conservation, and landowner assurances against damage. Streamline permitting and planning requirements.

- Make groundwater recharge a part of climate adaptation plans (which local governments are required to produce under the state's climate legislation).

- Publicize broadly the benefits of groundwater recharge on agricultural lands.

- Make state water bond funding available, explicitly, for such projects.

- Provide a property tax benefit for keeping land in a state that facilitates groundwater recharge, through a mechanism similar to that used to incentivize conservation of agricultural land under the Williamson Act.

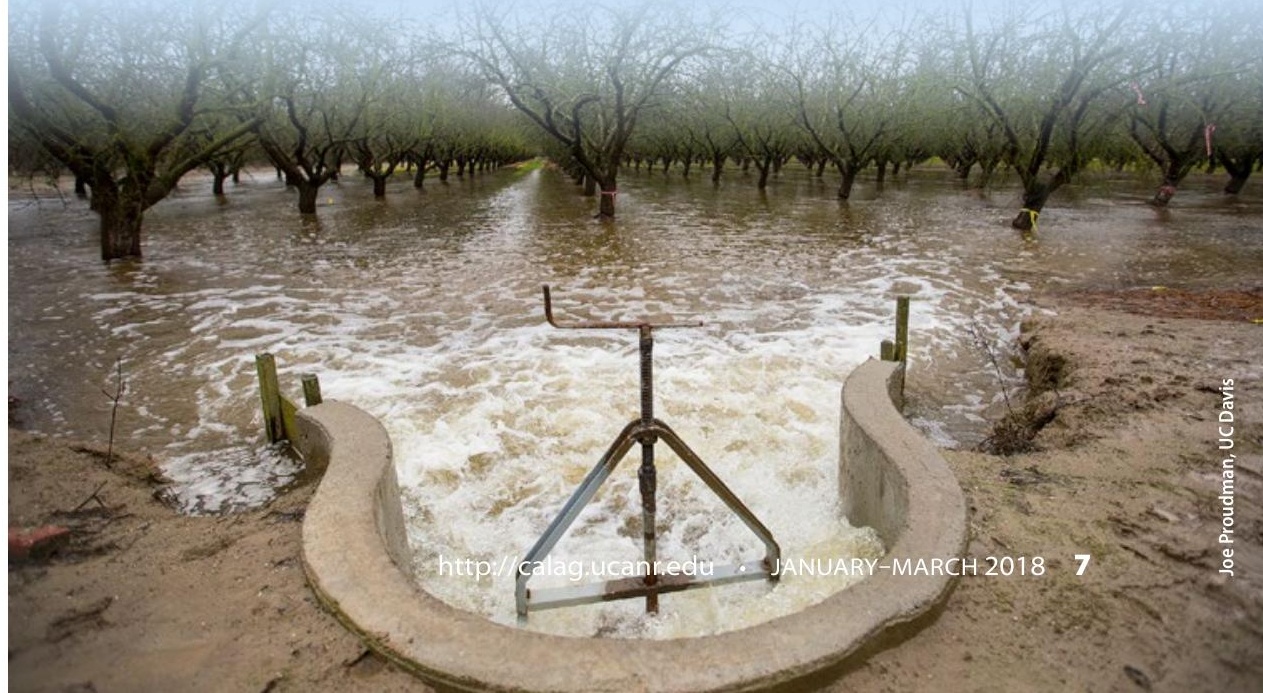

